\title{
Negotiating with the Bandits and Endless Security Challenges in Katsina State, Nigeria (2019-2020)
}

\author{
Muhammad Abdullahi Maigari, ${ }^{1 *}$ Umar Dantani, ${ }^{2}$ Ibrahim Arafat $^{3}$ \\ ${ }^{1}$ Department of Sociology, Al-Qalam University, Katsina - Nigeria, ${ }^{2}$ Department of \\ Political Science, Usmanu Danfodiyo University, Sokoto - Nigeria, ${ }^{3}$ Gombe State \\ University, Gombe - Nigeria
}

\begin{abstract}
The activities of criminals have been on the rise and the security situation deteriorated after negotiations between the State Government and the criminals in Nigeria. This paper assesses the context of armed banditry, cattle rustling, and kidnappings in Katsina State. The researchers adopted a cross-sectional study design and explanatory research type. A field survey was conducted in Batsari town and two villages: Zamfarawa and Bakiyawa. In-Depth Interviews (IDI) were conducted with some residents of the villages and some armed bandits. A non-probability sampling and snowballing technique were adopted to sample the research participants for the interviews. The study found that the Katsina State Government has not understand fully the security challenge and hence identified the wrong leaders of the criminals for negotiation, this is because there are three categories of criminals in the areas. This incensed some of the groups of criminals to intensify their attacks, kidnapping, and the rustling of livestock.

Kegiatan para penjahat telah meningkat dan situasi keamanan memburuk setelah negosiasi antara Pemerintah Negara Bagian dan para penjahat di Nigeria. Artikel ini membahas tentang gerombolan bersenjata, pencurian ternak, dan penculikan di Negara Bagian Katsina. Peneliti menggunakan desain studi cross-sectional dan desain penelitian eksplanatori. Survei lapangan dilakukan di Kota Batsari dan dua desa: Zamfarawa dan Bakiyawa. Wawancara mendalam dilakukan dengan beberapa penduduk desa dan beberapa gerombolan bersenjata. Teknik sampling non-probabilitas dan bola salju diadopsi untuk memperoleh informan untuk diwawancarai. Penelitian ini menemukan bahwa Pemerintah Negara Bagian Katsina belum memahami sepenuhnya tantangan keamanan di wilayah itu dan salah dalam mengidentifikasi pemimpin penjahat untuk negosiasi, karena dalam hal ini ada tiga kategori penjahat di daerah tersebut. Kondisi ini membuat geram beberapa kelompok penjahat untuk meningkatkan serangan, penculikan, dan pencurian ternak warga.
\end{abstract}

Keywords: negotiation; armed banditry; kidnapping; cattle rustling; security challenges

*Corresponding Author: Muhammad Abdullahi Maigari (maigariabdullahi@auk.edu.ng), IBB way Dutsinma Road, Katsina, Nigeria. 


\section{Introduction}

Northern Nigeria has been embroiled in social conflicts and armed violence in recent times, from 1999 to 2000. Like other social phenomena, nature and causal factors have changed from ethnic and religious violence, which characterized the region from 1999-2009 to Islamic insurgency in the Northeast and armed banditry, kidnapping for ransom, and cattle rustling in the Northwest. In desperate attempts to find solutions to the armed banditry, kidnapping and cattle rustling, and sometimes sporadic killings of people and abductors by the criminals, Katsina State Government and Zamfara State Government called for a truce with the bandits in 2019. Anderlini (2004) underscores the importance of negotiation in ending violence, which he referred to as the catalyst for achieving durable peace and translates into society's social and economic development affected by the armed violence. However, on the side of the continuum, some scholars objected to negotiating with criminals who kidnap people for ransom because it often metamorphoses from crime to business and source of funding for financing the activities of the criminals. In Colombia and Mexico, kidnapping for ransom was a lucrative business and source of income for the criminals. Ransom from the abduction of people has contributed to the security challenges to persist in Latin America, especially the activities of the Revolutionary Armed Forces of Colombia was financed by ransom and illicit drugs money (Hansen 2003).

The armed bandits operating from a forest that cut across Kaduna Zamfara and the Katsina States have been terrorizing communities and villages in the States, abducted hundreds of people, displaced thousands of people, and killed many civilians and Nigeria's armed forces deployed to restore peace in the areas. Government, both Federal and State Governments in Nigeria, have been struggling to end the spate of violence and kidnapping in the Northwestern region. However, as Hofmann (2012) observed, in internal security challenges or insurrection, the government in such countries face non-state soldiers who are out to challenge the state institutions and their monopoly of force. Most of these actors in violence have different goals, including overthrowing the existing government, retaliation against social and economic injustice, seeking resource control, and demands for a sovereign state to promote and protect parochial interests ethnic or religious groups. However, in the case of armed bandits who have been carrying out their activities in some Northwestern States of Kaduna, Katsina, Zamfara, Sokoto and lately Kano, Jigawa and the Kebbi States are not an organized group with a centralized command of authority like terrorist organizations, rebels or drug cartels. There are bands, each operating within an enclave or territory, but the bands' leaders are familiar with each and know their sphere or domain of control. Buttressing the above assertions, the Center for Security Studies Zurich released a Report in October 2013 that showed that half of the global adduction cases in the half of 2013 were carried out in four countries and Nigeria has the highest kidnapping or abduction rate in the world. The countries are Nigeria (26\%), Mexico (10\%), Pakistan, and Yemen (7\%). Additionally, in $64 \%$ of abductions, ransoms were before the kidnapped people were freed (Center for Security Studies 2013). 
Dutton (2016) observes that ransom payments are the primary source of funds for terrorists worldwide, and it is on the increase because it has become a lucrative business for other criminals. This informed the G8 (Group of Eight) leaders in June 2013 to converge and issued a statement which classified payment of ransoms to terrorists contributes to funding new incidents of abduction for payment of ransom, and it also helps in strengthening the terrorist organization. The Statement further stressed that there should be a strategy to forestall future occurrences of abduction and securing the abducted safely without any financial commitment. Building on the decision of the G8, the United Nations Security Council in January 2014, also in a unanimous decision, adopted a resolution that expressed anxiety over the rise in the rate of hostage-taking for ransom by terrorist groups and how the money received by the terrorists as ransom helps in funding future abductions. The resolution instructed member states to avert kidnappers from benefiting from money received as ransom. The member states are encouraged to explore the potentials of NonGovernmental Organizations to intervene in the release of kidnapped persons without payment of ransom.

This paper is interested in contingent terrorists which are defined by the International Institute for Applied Systems Analysis (2009) as a group of terrorists or criminals who are mostly abductors and hostage-takers. This type of terrorist is willing to negotiate with either government or relatives of the captives to free the victims to collect ransom, attract publicity, use the captives as a tool for bargaining for their demands from authorities.
Faure (2008) and Meier (2018) consider four strategic options in facing terrorist actions such as hostage-taking, no negotiation, secret negotiation, regular negotiation, and negotiation to prepare for an assault. The 'no negotiation' policy aims to deter terrorists from taking more hostages and is, for instance, the official Israeli policy concerning the Palestinians. This option has the most painful consequences on the hostage condition. The 'secret negotiation' strategy is more commonly used, one of its major advantages being to remove negotiators from the influence of public opinion and the media. This was the case after the seizure of the US embassy in Tehran in 1979. The 'regular negotiation' option is used when there is no way of hiding the hostage-taking from public audiences, as was the case with the French journalists in Iraq when even the amount of money paid as a ransom was widely known. 'Negotiation for an assault' is another way to resort discussion process to collect information about the terrorists, such as the number of terrorists' details of their equipment and state of mind. It is also a means of exhausting them or altering their concentration levels before launching an attack. This is usually done when the environment is well controlled by the authorities. The storming of the residence of the Japanese ambassador in Lima is one of many cases belonging to this category.

Some relevant studies related to this topic had been done by schoolars, as Meier (2018), International Institute for Applied Systems Analysis (2009), Adetula, Murithi, \& BuchananClarke (2018), and Cronin (2010) who focused their studies on negotiation between govern- 
ment and terrorist groups. Meier (2018) examined how government of Peru and Columbia engaged terrorist group for negotiations and the implications of such a negotiations, and International Institute for Applied Systems Analysis (2009) found that the decision for negotiation with both contingent and absolute terrorist was a fault decision because negotiation in this context may be meant as encouraging terrorism. Adetula, Murithi, \& Buchanan-Clarke (2018) focused their study on state actors and opposition, not criminals and terrorists. The point of their study is the inability of the parties to abide by the clause of agreement that leads to a relapse of violence. Meanwhile the study of Cronin (2010) suggested that it could be best approached through a long-term and sustainable process, which requires patience, determination, broad intelligence gathering, and patriotism.

Adetula, Murithi, \& Buchanan-Clarke (2018) explain some of the reasons for the collapse of the peace agreement in some countries. This includes the inability of the parties to implement the clauses of the agreement faithfully. This could be referred to as non-compliance and nonacceptance of the tenets of the accord. A typical example of the collapse of the peace accord was the civil unrest in South Sudan where the parties in dispute failed to work in line with the Peace Agreement signed in 2015. Therefore, resultant effects of non-compliance to the peace accord often lead to political uncertainty, societal tension, and disputes. This work of Adetula, Murithi, and Buchanan-Clarke primarily focused on state actors and opposition, not criminals or terrorists. However, what is interesting about this work is how the parties' inability to comply with the agreement clauses caused the violence to recur. This is akin to the agreement between the Katsina State Government and leaders of armed bandits in 2019 when the government, fulfilled their part of the agreement, whereas the bandits reneged on their promises and continued with their attacks and kidnapping of unarmed civilians. Katsina State has entered a peace accord with the armed bandits in 2019 but notwithstanding, the attacks and abduction of people have continued unabated.

Shortland and Tom (2017), Peel (2017) Mellon, Bergen and Sterman (2017), Echeverría Jesus (2018), Center for Security Studies (CSS) Zurich (2013), and the Telegraph (UK) (2007), British Counter-Terrorism and Security Bill (2014) are some who focused their study on ransom stated by the terrorist and bandit groups. Based on the studies taking place in many countries, as Peel (2017) in the coastal area of Malaysia, Mellon, Bergen and Sterman (2017) among Al-Qaeda in the Arabian Peninsula, Echeverría Jesús (2013) in West Africa, ransom payment for the bandits or terrorists only helps the continuation of the activities of criminals.

Generally, groups of terrorists got financial support from kidnapping and any other violences. Only some groups that had a strong financial support so they did not need that ransom. But these groups kidnap people to attract the attention of the world and compel the government to make a concession to their demands or demonstrate their level of strength. In contrast, some rely on ransom for funding their group and hence continuation of kidnapping or hostage-taking. 
Echeverría Jesús (2013) studied how some terrorist organizations have adopted kidnapping as an operational mechanism and source of funds for running their organization. examined kidnappings by two terrorist groups in Africa: Movement for Oneness and Jihad in West Africa (MUJAO) and AQIM (Al-Qaida in the Lands of Islamic Maghreb). The terrorist groups kidnapped 17 Europeans in Algeria who were later released from captivity in the Northern region of Mali in August 2003 after negotiation and payment of ransom. The Malian Government appointed the leader of the Terrorist in West Africa, Iyad Ag-Ghali as the intermediary where the sum of Five Million euros was paid as ransom before the European hostages were released. Since then, the cases of kidnapping of tourists, aid workers, and travellers have increased by the terrorists in the region. The study found that AQIM has received millions of Euros from kidnapping Western nationals between 2007 and 2008 in Algeria, Mauritania, Mali, and Tunisia. In 2009, Jesus revealed that AQIM received Seven Million euros as a ransom for the kidnapping of aid workers from Spain. As part of the negotiation for the release of the hostage, AQIM demanded the release of their member Ahmad Ould Hamma was sentenced to twelve years imprisonment for acts of terrorism in Mauritania. Out of desperation to save the aid workers' lives, a ransom was paid and the Mauritanian government was persuaded to free the Ould Hamma. Two years after he was freed, Ould Hamma was found among those who plotted an attack carried out by a terrorist group in Nigeria called Boko Haram in 2011, killing dozens of soldiers and civilians in Borno State, Nigeria.
Center for Security Studies (CSS) in Zurich reported in (2013) that terrorist in groups in some parts of the world where there are weak democratic institutions and ungoverned spaces, kidnapping people for ransom is the major source of income for the groups. The report observes that ransom payments to criminal groups are among the major challenges for security personnel and governments in the area's kidnappings are at their peak. The report has established that Islamic fighters in the Sahel are using the money realized from kidnapping to lure new people into their groups, procure modern weapons, establish and equipping training grounds for the new and existing members, purchasing of Information Communication Technology facilities for communication, and other activities.

The British Counter-Terrorism and Security Bill (2014) declared that the British would no longer pay ransom for the kidnap of its citizens. The reason was that the ransom paid to terrorists or criminals ends up in the hands of arms dealers and gun manufacturers and is used to plan terrorist attacks and take foreign nationals' hostage. The Bill revealed in one year, that is, from 2013-2014, a terrorist organization called ISIL received approximately US Dollar $35 \mathrm{~m}-45 \mathrm{~m}$ as ransom from the abduction of people, especially Europeans and Americans. Additionally, from 2010 to 2014, another international terrorist group, Al-Qaida, and its conglomerates collected about USD145m as ransom from taking people hostage. That is, for each European or American kidnapped by the terrorists, an estimated USD 2.7-2.9m per was paid as ransom. The Bill has succinctly provided 
statistical estimates of ransom received by terrorist groups. Still, it has not provided evidence of how they used the ransom to procure weapons and initiate new attacks. However, the Bill has established a correlation or association between the amount of money received as ransom by the criminals and the continuation of kidnapping people for ransom by the same terrorist groups.

The Telegraph (UK) (2007) had an interview with one of the leaders of Taliban fighters in Afghanistan on how they utilize the ransom received from kidnapping foreigners until a ransom is paid. The leader stated they are using the money to sponsor their members to plan and carry out attacks on coalition armed forces in their country. He stated that they also sent the money to their members operating outside Afghanistan to launch attacks on their targets. The ransoms were also used to recruit new members and train them in Western counties, particularly the USA and Britain. These are members who are used to carry out attacks in their European countries and the US. The Commandant averred that a Ten Million US Dollar Taliban received in 2006 as a ransom for kidnapping Coalition soldiers was used to restock their arsenal and initiated an operation called Operation Nusra (Victory) in Southern Afghanistan, leading to the killing of four British soldiers.

The focus of this study in Katsina is on armed bandits who have some characteristics: 1) they are not well structured like international terrorist organizations, but they commit similar atrocities and collect a ransom in exchange for the kidnapped victims; 2) not like the terrorists in Colombia who put the goal for the establishment of a communist State in Colombia while SL in Peru has a moist ideology, the armed bandits in Nigeria have not clearly stated their political ideology or goals; 3 ) the specific nature of the attacks against civilians and the abduction of people for a ransom payment; 4) armed banditry and incessant kidnappings. Based on the above studies and the fact found in Katsina, this paper aims to examine the activities of armed bandits, kidnappers, and cattle rustlers in the Katsina States after the State Government negotiated with them to end their activities. This paper also aimed to examine how payments of ransom for the hostage have worsened the States' security situation.

This research has adopted a cross-sectional study design and explanatory research type. The study was conducted in Batsari Local Government Area in Katsina. Batsari is the most affected Local Government Area in Katsina State by the attacks, killings, and kidnapping of people for ransom. Therefore, the data were obtained from both primary and secondary sources. For the secondary data, documented materials from newspapers, journal articles, and textbooks were utilized whereas for the primary data, a field survey was conducted in Batsari town and two villages: Zamfarawa and Bakiyawa. In-Depth Interviews (IDI) were conducted with some residents of the villages and some armed bandits. Non-probability sampling was adopted because probability sampling will not be suitable in this research (Babbie 2013). Similarly, a snowballing technique was adopted to sample the research participants for the interviews. It is a sampling method adopted in a field study where each of the participants interviewed 
would be requested to connect the researcher with other people who share similar characteristics (Babbie 2013). The technique is considered appropriate because the targeted population is difficult to find and grant an interview. The researchers were able to establish a rapport with one of the armed bandits who was asked to link the researchers with other members of their group which he obliged. It is substantiated by Babbie (2013) that snowballing method of sampling is considered as the best when the participants or respondents are hard to be identified. A total of five (5) IDIs were conducted, three with the armed bandits and two with residents of the villages. The interviews were conducted in the Hausa language, transcribed verbatim, and translated to the English language. The data were coded and analysed using prose style based on the research objectives.

\section{Peace Agreement with the Armed Bandits in Katsina}

The Governor of Katsina State together with the Governors of Zamfara, and the Sokoto States had on August 28, 2019, negotiated with the armed bandits that have been operating the three States. During the negotiation for a peace deal, the Inspector General of Police also participated in thediscussion with some leaders of the armed bandits and kidnappers. Part of the agreement was the release of the armed bandits arrested by the security operatives who the Court has not convicted, rehabilitation of rural infrastructure and social services. While on the armed bandits, they are expected to lay down their weapons and discontinue from launching attacks and kidnapping people for ransom and release people in their custody. Between August and October 2019, there was relative peace and few incidences of kidnapping in Katsina State. However, from December 2019 to December 2020, the State has witnessed intense attacks on villages, setting houses ablaze and ransacking of properties as well as rampant kidnapping of people in both villages and urban areas particularly in Batsari, Kankara, Danmusa, and Safana Local Government Areas of the State.

Based on the above background, all three bandits stated during IDI sessions that the Government has negotiated and signed a peace deal with a segment of the bandits not all. Those who agree with the Government have no power to direct or instruct other bands of criminals who are not under their control. One of the armed bandits Bakiyawa Village averred that:

"Each village has its groups and their leaders. We operate independently but we know members of the band. Therefore, if the Government had a dialogue with bandits or those kidnappers in Danmusa LGA or Kankara, we will not know what they discussed with the Government. Many of the bandits in the forest are not aware of the agreement until after some months."

Narrating further, an armed bandit in Zamfarawa Village explained that:

"The major issue is that the Government dialogued with the wrong people. Most of the people invited by the Government hardly go to operation either cattle rustling or kidnapping. You see, if the field operators are not aware of the ceasefire, how do you expect peace in the area?"

Similarly, an armed bandit in Batsari expressed a different perspective of the peace deal with the government and stated thus: 
"Like in your band, we have other bands operating in Jibiya LGA down to Zurmi in Zamfara State but we have not been invited even the people released by the government, members of our band have not been freed. That is the reason we do not have reason to stop our operation. You have seen our condition here; do you see any social amenities here? Have you seen anything to indicate this place is in Nigeria?"

It could be deduced from the above qualitative data that the success or failure of an agreement or negotiation largely depends on the selection of appropriate leaders of non-state actors for dialogue. This implies that the majority of the leaders of armed invited by the Government were legitimate leaders within their bands alone. Therefore, Government and nonGovernmental Organizations find it very difficult to identify the leaders with a broad sphere of command and authority who can influence the other bands to lay down their arms. This correlates with the findings of Cunningham and Sawyer (2019) on the difficulty encountered in identifying leaders of the Syrian rebels for a round table dialogue. The rebels are increasingly divided, with splinter groups, each operates independently, the preference on who should be invited for the dialogue or negotiation is a tasking exercise. Similarly, it is also in line with the findings of Barltrop (2008) in Burundi after the negotiations and series of peace talks in the country to end the civil unrest between the government and the rebels. After the peace talks and agreement, it has found that some rebels groups refused to submit their weapons to the Government. Additionally, some of the rebel leaders who surrendered their weapons and received money from the government used it to purchased new weapons at a lower price, remobilized surrendered rebels, and present them to Government to receive the new benefit. Additionally, Felbab-brown (2020) observe that understanding the context of violence and personalities involved in the violence or war, before going to the negotiation table. Furthermore, Cronin, (2010) negotiation with the criminals does not often lead to an automatic end to violence or criminal activities.

The findings indicate that the Government of Katsina Stae lacked adequate knowledge of the armed bandits' organizational structure, operational strategies, and leadership. Therefore, understanding the operational matrix and forming the armed bands of kidnappers and cattle rustlers determines who should be invited for negotiation or dialogue to avoid excluding others who may turn to be spoilers. Heger and Jung (2017) cautioned that when negotiating with the rebels, spoilers may come up to disrupt the peace process and agreement when they felt they were deliberately or wrongly omitted or not invited to participate in the peace process or people do not have a stake in the violence are involved in the negotiation process, spoilers tend to take up an arm and continue fighting. Furthermore, Wanis-St. John (2008) concludes that negotiation between Government and armed groups is one of the most sensitive parts and difficult in the negotiation process.

\section{Payment of Ransom}

All the three members of the armed groups interviewed were unanimous in their views that they were into the act of kidnapping because of the ransom. Most of the villages in Batsari have no grudges between the nomadic Fulani and 
peasant farmers who are mostly Hausa people. The influx of some armed bandits from Zamfara State through a forest called Rugu which run across three States, Kaduna, Katsina, and the Zamfara States, have lured some of the bandits in parts of Katsina State into the business. It has been observed that the factors that triggered conflict between the farmers and herders in Zamfara are not what instigated the violence and insecurity in some parts of Katsina State. An armed bandit in Zamfarawa Village during IDI narrated that:

"We were rendered idle because our livestock was rustled by our fellow herdsmen. We became worried with nothing to feed ourselves and our family. Then some armed bandits from Zurmi and Kauran Namoda areas in Zamfara came to our areas and discussed with us whether we can join the gang to regain our stolen livestock. Initially, we joined armed banditry intending to get money to buy livestock and continue with our traditional herding and stop stealing. But as you know, this act is so enticing, without any suffering, you succeeded in kidnapping a wealthy person or rustled a homestead, and you would get up to One Million Naira."

Similarly, an armed bandit in Bakiyawa village recounted his experience of hostagetaking and ransom collection. He stated that:

"It is very hard to get a job or business that would get what we are getting at least weekly. You know it is not every day we kidnap and succeed; your security agencies and people are after us. We preferred to kidnap a person that Government would pay the ransom than individuals. You know Government likes long grammar but if it is an ordinary person, they pay the ransom quickly no matter how small the amount it is. We are aware of those who collected money from the Government as part of the settlement. The leaders of the groups shared the money with their boys and most of the boys are now independent, they have their band now. Except Government has succeeded in killing the entire bandits inside the Forests in the Northwest, I do not see armed banditry and kidnapping ending soon. This is a money-making venture. All you need is a gun and motorcycle and a tipoff from informants in the town."

Furthermore, during an IDI with an armed bandit in the suburb of Batsari town, he explained that he can acquire his gun from the share he received after they abducted some people along Katsina-Dutsin-Ma Road in March 2020. He further explained that most of the band leaders were able to form their bands when they received a substantial amount of money from the kidnapped people. He submitted that:

"This is what is encouraging some youth, mostly idle to join us and once you can succeed in an operation and received a huge ransom if you have a generous group leader, he can give you a reasonable amount of money that you can purchase your gun. From there, continuously, you will be buying guns and recruit new boys and establish your group, you become a leader. This is how the bands keep increasing in these areas, nobody can tell accurately how many bands are there even in Batsari alone not to mention the entire forest from here to Jibiya down to Zamfara or from here Danmusa to Kankara."

Corroborating the narratives of the armed bandits, a resident and a community leader in Batsari revealed that locals have now adopted to life with the armed bandits. This is because they have exhausted all their valuable properties and nothing else, remain to sell to pay a ransom. The Government and security personnel are doing little to end the activities of the armed bandits in these areas. As part of the coping strategy with the insecurity, a resident of Batsari stated that: 
"In Zamfarawa village which was attacked by the armed bandits more than ten times, every adult or household now has a gun. Instead of paying a ransom to the armed bandits who in turn buy weapons to kill us, we resorted to buy weapons and keep to defend our people and livestock. We are a farming community and these cattle are significant to farming and as an asset. This is our collective effort to defend ourselves because we observed that payment of ransom has been encouraging them to kidnap people and form new bands. This is happening because of the inability of the security personnel to protect the villagers and eliminated the criminals in the adjoining forests."

Similarly, a community leader in Batsari narrated that:

"Since the inception of armed banditry and kidnapping around 2016 in these areas, I don't know any person who joined the group and has repented. Most of the bandits or rustlers I know ended up being killed by the mob or security agents. This is because the business is generating a lot of money and if they leave it, where would they get the money? Don't have livestock and people in the community are aware they are criminals which means they cannot live in the community with their people for fear of lynching. It is very difficult for a person who is used to collected Millions of Naira to leave the acts and live-in poverty, ransom has spoiled the bandits more than anything. Fe kilometres away from the town, you find camps of the armed bandits, living freely. On several occasions informed the Government and the security personnel but no action was taken to clear them from our Forests. So long as they are there in the Forest, all the neighbouring villages will not be in peace. The bandits often blame the villagers for giving intelligence reports to the security agents whenever there is an attempt to attack by the soldiers."

Deducing from the qualitative data, the narrations and submission from the interviews have provided a contextual explanation for the rising rate of kidnapping for ransom in some parts of Katsina. The ransom payment has contributed to the formation of new bands of kidnappers and such money, cajoled some people into the acts. The findings also indicate that the absence of a mechanism by the security agencies to ensure the release of those in captivity without payment of ransom is among the factors that contributed to the deterioration of the security situation in the areas. This is related to the conclusion of Brandt, George, \& Sandler (2016) who concluded that the more a terrorist group receives ransom or concessions from the government, the more abduction or kidnapping they would initiate new attacks to obtain more gains. In the same vein, the findings have been corroborated by the submission of Shortland and Tom (2017) which observe that when criminals or abductors realized or suspected it is the Government that would pay the ransom, there is a tendency that they would demand an exorbitant amount of money; because of the belief that Government has enough funds in its treasury. Corroborated by Financial Action Task Force (FATF) (2011:34) report: money received in exchange for a hostage is found to have a direct effect on the viability of the armed groups to run their affairs and sponsor new attacks and abductions which found to be a major source of budget financing or revenue that finance the budget of AQIM.

The findings revealed that the villages visited could be described as ungoverned spaces, apart from Batsari town which is the Headquarters of the Local Government Area, whereas inthe remaining villages there was no presence of 
Government either security personnel or social infrastructure which enabled the armed bandits and cattle rustlers to attack such villages with ease, kidnap people, rustle livestock and ransack foodstuff without any assistance from the security operatives deployed in Batsari. The findings indicate that armed banditry, kidnapping, and the rustling of livestock thrive in the areas because of the absence of government, especially security personnel and social infrastructure which disconnected the villages from urban areas. This correlates with Munyua (2015) finding, which found a relationship between ungoverned space and insecurity in developing countries. Many African and other developing countries are faced with the problems of ungoverned areas which have now become a haven for the terrorists, armed bandits, insurgents, rebels, and kidnappers. Similarly, Abasa et al. (2015) on how ungoverned spaces contributed to the thriving of the Lord Resistance Army in Uganda and other armed groups operating in East Africa.

\section{Conclusion}

This study has provided a contextual investigation of the armed banditry and kidnapping that besieged some parts of Katsina State. An attempt has been made to examine the negotiation between the armed bandits and the Katsina State Government in August 2019 and the subsequent deterioration of the security situation in less than a year. In this context, the Government lacked in-depth knowledge of the working and structure of the armed bandits and kidnappers in the State which was reflected in the selection of band leaders for dialogue. This has generated a lot of disaffection among leaders of the bands who were not invited for negotiation, the release of their arrested members, and financial assistance from the government. That is, a proper understanding of the nature and composition of the armed groups is essential, identification of groups within each community and their leaders are essential criteria for the selection of leaders of the armed groups for dialogue, negotiation, or peace talks as well as the signing of the peace accord to avoid backlash from the spoilers. Therefore, the incessant attacks on villages and kidnapping and burning of houses by the armed bandits in 2020 in Batsari Local Government Area could be attributed to the work of spoilers among the armed bandits who were not part of the agreement entered in August 2019 with the Government.

The payment of ransoms for kidnapping by both constituted authorities and private individuals has contributed to the sustenance of the existing armed groups and new ones. Ransom's payment has become a reliable source of income for the bandits and kidnappers and uses the ransom to procure weapons, feed, and fund operational logistics for carrying out attacks. Without payment of ransom, the majority of the bandits would have ceased to exist due to a lack of funds for the procurement of weapons alone. The absence of efficient operational strategy by the security agencies to rescue people abducted without payment of ransom has compelled relatives of the captives or captives to pay ransom to save their lives. This contradicts with the findings of Hyatt, Fernandez, \& Rollins (2016) who found that the 
policy adopted by the United States of America for not paying a ransom to hostage-takers has not demoralized the criminals to stop; on the contrary, it has skyrocketed.

Drawing from the above findings and conclusion, below are the recommendations: 1) Government should demonstrate the superiority of force by defeating the armed groups before inviting the armed groups for negotiation. 2) The government should avoid making hasty decisions in selecting the leaders of armed groups for dialogue, negotiation, and peace pact. 3) Security agencies should develop an alternative method for rescuing those abducted other than payment of ransom.]

\section{References}

Abasa, Africano, Carolyn Halladay, and Florina Cristiana Matei. 2015. "Ungoverned Spaces and the Survival of Terrorist Groups in Africa: A Case Study of the Lord's Resistance Army." Naval Postgraduate School Monterey, California.

Adetula, Victor, Tim Murithi, and Stephen Buchanan-Clarke. 2018. Peace Negotiations and Agreements in Africa - Why They Fail and How to Improve Them. Uppsala: The Nordic Africa Institute.

Anderlini, Sanam Naraghi. 2004. "Peace Negotiations and Agreements." Pp. 16-32 in Inclusive Security, Sustainable Peace: A Toolkit for Advocacy and Action (2) - Conflict Prevention, Resolution and Reconstruction. London: International Alert, The Initiative for Inclusive Security - Women Waging Peace.

Babbie, Earl R. 2013. The Basics of Social Research. Boston, MA: Cengage Learning.
Barltrop, Richard. 2008. "The Negotiation of Security Issues in the Burundi Peace Talks." Centre for Humanitarian Dialogue, Country Study (1).

Brandt, Patrick T., Justin George, and Todd Sandler. 2016. "Why Concessions Should Not Be Made to Terrorist Kidnappers." European Journal of Political Economy 44:41-52. doi: 10.1016/j.ejpoleco.2016. 05.004 .

Center for Security Studies. 2013. "Kidnapping for Ransom as a Source of Terrorism Financing." CSS Analysis in Security Policy 141,1-4.

Counter-Terrorism and Security Bill. 2014. Factsheet-Part 6 Clause 34-Kidnap and Ransom 1-2.

Cronin, Audrey Kurth. 2010. "When Should We Talk to Terrorists?" Special Report 240: 116. Retrieved (https://www.usip.org/ publications/2010/05/when-should-wetalk-terrorists).

Cunningham, Kathleen Gallagher, and Katherine Sawyer. 2019. "Conflict Negotiations and Rebel Leader Selection." Journal of Peace Research 56(5):619-34. doi: 10.1177/ 0022343319829689.

Dutton, Yvonne M. 2016. "Funding Terrorism: The Problem of Ransom Payments." Digital USD - University of San Diego. Retrieved (https://digital.sandiego.edu/ sdlr/vol53/iss2/4/).

Echeverría Jesús, Carlos. 2013. “Kidnappings as a Terrorist Instrument of AQIM and the MUJAO." Paix et Securite Internationales (1):161-66. doi: 10.25267/Paix_secur_int. 2013.i1.11.

Faure, Guy Olivier. 2008. "Negotiating with Terrorists: A Discrete Form of Diplomacy." The Hague Journal of Diplomacy 3(2):179200. doi: 10.1163/187119108X321512. 
Felbab-brown, Vanda. 2020. Bargaining with the Devil to Avoid Hell? A Discussion Paper on Negotiations with Criminal Groups in Latin America and the Caribbean. Barcelona: Institute for Integrated Transitions.

Financial Action Task Force. 2011. "President's Summary of Outcomes from the Expert's Meeting on Corruption." FATF 34.

Hansen, Susan. 2003. "High Net Worth Families, Kidnapping Risk." Trusts \& Estates 35.

Heger, Lindsay L., and Danielle F. Jung. 2017. "Negotiating with Rebels." Journal of Conflict Resolution 61(6):1203-29. doi: 10.1177/0022002715603451.

Hofmann, Claudia. 2012. "Reasoning with Rebels. International NGOs' Approaches to Engaging Armed Groups." SWP Research Paper 1-28. Retrieved (https://www.swpberlin.org/en/publication/ingosapproaches-to-engaging-armed-groups/).

Hyatt, Rodney, Lauren Fernandez, and John Rollins. 2016. "Granting Concessions and Paying Ransoms to Terrorists: A Policy Options Analysis of the U.S. Policy on Hostage Recovery." Naval Postgraduate School Monterey, California.

International Institute for Applied Systems Analysis. 2009. "Negotiating with Terrorists: A Mediator's Guide." IIASA Policy Brief 6:1-4. Retrieved (https://iiasa. ac.at/web/home/resources/publications/ IIASAPolicyBriefs/pb06.html).
Meier, Anna. 2018. "Bargaining as a Process of Legitimation: A Theory of State-Terrorist Negotiations." in ISA 2018.

Mellon, Christopher, Peter Bergen, and David Sterman. 2017. "To Pay Ransom or Not to Pay Ransom? An Examination of Western Hostage Policies." International Security, January 8.

Munyua, David 0. 2015. "Ungoverned Spaces and Armed Civil Conflicts: The Predicament of Developing Nations." Naval Postgraduate School Monterey, California.

Peel, Michael. 2017. "Islamist Militant Piracy Troubles Philippines." Financial Times. Retrieved (https://www.ft.com/content/ 0f23b6aa-eeb3-11e6-930f061b01e23655).

Shortland, Anja, and Keatinge Tom. 2017. "Closing the Gap: Assessing Responses to Terrorist-Related Kidnap-for-Ransom." RUSI Occasional Paper 1-32.

The Telegraph (UK). 2007. Byline: Massoud Ansari in Kila Abdullah, Pakistan. London: Telegraph.

Wanis-St. John, Anthony. 2008. "Peace Processes, Secret Negotiations and Civil Society: Dynamics of Inclusion and Exclusion." International Negotiation 13(1):1-9. doi: 10.1163/138234008X297887. 
This page has been intentionally left blank.

JSW (Jurnal Sosiologi Walisongo) - Volume 5, No. 1 (2021) 